\title{
Towards an Integrated Model of the U.S. Supreme Court's Federalism Decision Making
}

\author{
Paul M. Collins Jr.*
}

Disputes involving the boundaries of state versus federal power make up a substantial portion of the U.S. Supreme Court's docket and have undergone extensive analysis. Yet, the conventional wisdom regarding the justices' choices in these cases is that they are highly inconsistent. I argue that this is primarily a function of the failure of scholars to develop a comprehensive model of the justices' federalism decision making. To remedy this, I introduce an integrated model of the individual justices' choices in these cases, which is then subjected to empirical testing in the Rehnquist Court era (1986-2004). I explore a host of determinants of the justices' decision making, including attitudinal, institutional, legal, and personal attributes, as well as the role of organized interests in the Court. The findings reveal that the choices justices make in these cases are not as discordant as most commentators suggest. Rather, they are relatively predictable through the application of an integrated model of judicial choice.

Each term, U.S. Supreme Court justices adjudicate disputes implicating the limits of federal versus state power. Through these federalism decisions, the justices are charged with determining the proper balance between the authority of states to operate as sovereign entities, free from federal interference, and the expansiveness of the federal government's reach under the Constitution. The importance of this debate is perhaps no more evident than in scholarly analyses of the Rehnquist Court's so-called "federalism revolution," in which the justices, under the leadership of Chief Justice Rehnquist, are argued to have reinvigorated the concept of taking states' rights seriously to a level that had not been witnessed since before the New Deal (Chen 2003; Greenhouse 2001; Pickerill and Clayton 2004). In so doing, the Rehnquist Court appeared to breathe new life into conspicuously long-forgotten constitutional provisions involving federalism as it struck down federal laws involving a wide range of social policies, including the regulation of firearms on school property (United States v. Lopez [1995]), violence against women (United States v. Morrison [2000]), and the free exercise of religion

*University of North Texas

Publius: The Journal of Federalism volume 37 number 4, pp. 505-531 doi:10.1093/publius/pjm019 
(City of Boerne v. Flores [1997]). In addition, the Rehnquist Court took steps to shield states from lawsuits under the Eleventh Amendment, despite congressional attempts to abrogate states' sovereign immunity (Seminole Tribe v. Florida [1996]). While these decisions, and many others, offer clear examples supporting the apparent importance of federalism to the justices, some believe otherwise, noting that, rather than signaling a genuine shift in the Court's federalism jurisprudence, these cases are merely examples of Rehnquist Court justices using the guise of federalism to strike down politically liberal policies in pursuit of their own conservative political goals (Colker and Brudney 2001; Cross 1999). Supporting this perspective, for example, researchers point to Bush v. Gore (2000), in which the Court's federalist five abandoned their seemingly staunch support for states' rights to usher George W. Bush into the White House (Segal and Spaeth 2002, 2; Solimine 2002). ${ }^{1}$ Still, other scholars have noted that the Rehnquist Court's federalism revolution cannot be wholly captured by either of these perspectives, and instead is best interpreted through a host of approaches, including a consideration of the justices' background characteristics (Schenker 1982; Young 2005) and institutional constraints implicated by these cases (Eskridge and Ferejohn 1994; Tiller 1995).

The purpose of this article is to develop an integrated model of the justices' federalism decision making and to subject this account to empirical scrutiny in the Rehnquist Court era. Investigating the Court's federalism jurisprudence is significant in a number of ways. First, despite the fact that there are literally hundreds of books and articles devoted to the topic, the cyclical nature of the justices' federalism decisions makes it one of the most erratic issues confronted by the Court and the inconsistency with which constitutional provisions are applied to similar cases only increases this ambiguity (Baybeck and Lowry 2000; Perry 2005; Wise and O'Leary 1992; Young 2005). Perhaps Bednar and Eskridge (1995, 1447) put it most succinctly when they described the Court's federalism cases as "a mess." Thus, we are clearly in need of an explanation of federalism decision making that can resolve some of this confusion. Second, notwithstanding the elusive nature of the Court's federalism jurisprudence, the issues implicated by these cases are among the most significant in the American political system. For example, these cases encompass a wide array of perennially salient disputes, ranging from age discrimination (Kimel v. Florida Board of Regents [2000]) to physician-assisted suicide (Washington $v$. Glucksberg [1997]) to reproductive rights (Webster v. Reproductive Health Services [1989]). Thus, absent a clear understanding of these cases, it is nearly impossible to comprehend the choices justices make in these highly important issue areas. Finally, unearthing the determinants of the justices' federalism decision making is important because the cases at issue involve one of the most important debates in American politics-the boundaries between state and federal power. Indeed, Justice O'Connor has refereed to the Court's 
responsibility to define the frontiers of federalism as the nation's "oldest question of constitutional law."2

In an effort to develop a comprehensive explanation of the justices' federalism decision making, this analysis is distinguished from previous research in two ways. First, it is novel as an initial foray into building an integrated model of the Rehnquist Court's federalism decisions. That is, rather than focusing on one or two attributes of decision making in these cases, I examine a host of factors, including judicial attitudes, background characteristics, institutional constraints, organized interests, as well as the possible influence of a jurisprudential regime created in United States v. Lopez (1995). As such, this research aims to offer a more complete picture of the justices' federalism decision making than currently exists. Second, unlike previous examinations of the Court's federalism cases that focus on a small subset of cases, ${ }^{3}$ this analysis considers all cases in which a state or local law was in conflict with a provision of the U.S. Constitution or congressional statute, as well as those cases in which a federal law was challenged as being in conflict with a provision of the Constitution relating to state's rights. In short, this research contains the universe of cases that encompass the boundaries of states' rights versus federal power decided in the Rehnquist Court.

This article proceeds as follows. In the next section, I develop and formulate several hypotheses related to the justices' decision making in federalism cases. I then subject these hypotheses to empirical testing using data on the justices' voting behavior in the Rehnquist Court. Next, I present an interpretation and discussion of the findings. I close with a brief conclusion section discussing how we might best characterize the justices' federalism jurisprudence and offer directions for future research.

\section{Explaining the Justices' Federalism Decision Making}

This section addresses factors that are hypothesized to influence the individual justices' decision making in federalism cases. These proposed determinants include the application and extension of the attitudinal model, background characteristics, a jurisprudential regime, institutional constraints, and the role of organized interests. I treat each in turn.

\section{The Attitudinal Model}

According to the attitudinal model of Supreme Court decision making, the justices' voting behavior is primarily motivated by their policy preferences (Segal and Spaeth 2002). That is, liberal justices vote liberally, while conservative justices vote conservatively. Although the attitudinal model is generally applied to explain cases on the basis of the policy dimension they involve (e.g., defining the case in terms of the liberal or conservative direction of the policy), scholars have also explored 
the model's applicability to federalism cases (Solberg and Lindquist 2006; Spaeth 1985; Young 2005) by investigating the application of the justices' attitudes as they relate to cases that also embody a federalism dimension (that is, the boundaries of state versus federal power). At its most basic level, the attitudinal model predicts that conservative justices will vote to uphold the validity of state or local laws under challenge, while liberal justices will vote to strike down those laws in an effort to expand the powers of the federal government. This is the case because conservative justices-following in part the pro-states' rights position held by the Republican Party—are expected to attach special significance to decisions that limit federal regulation over issues viewed as falling under the purview of state jurisdiction. Conversely, liberal justices-following in part the pro-federal government stance of the Democratic Party-are expected to push for decisions that stress social and economic equality, and thus require action by the federal government (Fallon 2002). ${ }^{4}$ As such, I hypothesize that conservative justices will be more likely than their liberal counterparts to endorse positions forwarded by state and local governments.

Of course, it is important to note that this somewhat reductionist version of the attitudinal model assumes that the justices deem federalism to be an important consideration in their decision making. That is, it presupposes that the justices take the federalism dimension seriously, regardless of how a case measures up on its policy dimension. However, it is not uncommon for a case's federalism dimension to conflict with its policy dimension (Baybeck and Lowry 2000). Consider Bush v. Vera (1996), in which the Court adjudicated the constitutionality of a Texas redistricting plan that was aimed at increasing minority representation. The liberal position on the policy dimension is in support of the redistricting plan as the plan sought to expand the voting power of minorities in three Texas congressional districts. The liberal position on the federalism dimension is against the plan as it sought to supersede the power of Congress and the federal courts to regulate electoral practices under the Voting Rights Act. Thus, this case provided almost ideal conditions to test how seriously the justices take federalism issues. That is, would the federalist five (Kennedy, O'Connor, Rehnquist, Scalia, and Thomas) stick by their apparently staunch support for states' rights and authorize the redistricting plan or would they abandon this position and strike down the plan as a violation of the Fourteenth Amendment? In the end, the policy dimension prevailed. By a 5-4 vote, the Court's majority struck down the plan as a violation of the Fourteenth Amendment and the only serious discussion of the federalism issues implicated by the case appeared in the dissenting opinion written by Souter and joined by Breyer and Ginsburg (Cross 1999, 1310). It is precisely the cases similar to Bush v. Vera that have led scholars to posit that the justices do not take federalism issues seriously, unless both the federalism and policy dimensions allow the justices to further their ultimate policy goals 
(Abernathy 1996; Baybeck and Lowry 2000; Colker and Scott 2002; Cross 1999; Solberg and Lindquist 2006; Tiller 1995; Young 2005). Instead, scholars in the attitudinal tradition have developed a theory of results-oriented federalism in which the justices-liberal and conservative-use the rhetoric of federalism to advance their policy goals. Following this, I hypothesize that, as the ideological proximity between a justice and the state or local policy increases, so too will the likelihood that the justice will vote in favor of the state or local policy at issue.

As a final extension of the attitudinal model, I expect that a case's salience will serve to enhance the extent to which the justices rely on their policy preferences in adjudicating federalism disputes. When a case involves a substantial policy issue, it compels a justice to more seriously consider how voting in favor of the federalism dimension might be at odds with his or her more general policy goals (Young 2005, 2). Conversely, in a case that does not activate a justice's substantial policy concerns, that justice might be more willing to sacrifice his or her policy goals for the sake of appearing to seriously consider the federalism issues subsumed by the case. This is perhaps no more evident than in Bush v. Gore, where the conservative federalist five abandoned their ostensible commitment to protecting states' rights to ensure an electoral victory for George W. Bush (Solimine 2002). Indeed, recent analyses of the relationship between case salience and the attitudinal model appear to support this perspective. For example, Unah and Hancock (2006) provide evidence that the attitudinal model better explains high salience cases precisely because the issues presented in important cases are most likely to implicate substantial policy concerns. While not addressing federalism cases per se, their logic is nonetheless applicable to the current analysis. If case salience matters, I expect that attitudinal-based voting will become especially enhanced in prominent cases. Thus, I hypothesize that salient cases will increase the likelihood of observing justices who are ideologically distant from the state or local policy cast votes against those policies.

\section{Background Characteristics}

In addition to attitudinal considerations, I also theorize that a justice's experience in state or local politics will influence his or her decision making. While students of judicial politics have long noted the importance of background characteristics in explaining judicial choice (Tate 1981), their application to federalism cases has been limited (but see Schenker 1982; Young 2005). I expect that justices who have served in state or local government office prior to their appointment to the Court will be more sympathetic to states' rights claims. This is due to deeply held attachments to the notion that states should be able to experiment with policy innovations, free from federal interference, on the basis of having personal experiences in developing those policies themselves. For example, 
as Kissam (2006, 780) notes, Chief Justice Taney's staunch adherence to states' rights positions in federalism cases grew from his upbringing in an intensely localized culture, including his experiences as a Maryland state legislator, senator, and attorney general. Justice O'Connor perhaps best personifies this perspective more recently, having served as an assistant state attorney general, a state legislator, and a state appellate judge in Arizona. She brought to the bench an earnest local perspective having been versed in the many dilemmas confronting state and local governments and this sense of localism shaped her federalism positions on the state appellate bench through increased empathy for state and local governments (Schenker 1982). Indeed, in lamenting O'Connor's departure from the bench for the future of states-oriented federalism, Young $(2005,43)$ proposes that it is unlikely that Chief Justice Roberts and Justice Alito will share her devotion to limiting federal power, despite their conservative credentials, since they lack strong attachments to "a particular state political community that generates a sense of state institutions as competent and important." If O'Connor's experience is generalizable to her counterparts with similar ties to state and local politics, and to her own experience on the Supreme Court, I hypothesize that justices with prior state or local political experience will be more likely to support state or local policies than justices without such experience.

\section{The Lopez Regime}

Students of courts have long debated, and tested, whether the law influences Supreme Court decision making (e.g., Mendelson 1964; Perry 1991; Segal and Spaeth 2002). Most recently, Richards and Kritzer (2002) developed a model of jurisprudential regimes, which are precedents thought to constrain the justices' decision making by establishing which case factors are relevant to their decision making. While the justices are free to ignore such regimes if they see fit, these authors provide compelling evidence that the justices take regimes seriously in a variety of contexts, deciding cases differently after the establishment of various regimes (Kritzer and Richards 2003, 2005). Following Richards and Kritzer (2002), I identified a candidate regime by examining key precedents that implicated the justices' federalism decision making decided during the Rehnquist Court era and established which case fact was relevant to that regime. While a variety of important federalism cases were decided during this period, United States v. Lopez (1995) stands out as a particularly relevant candidate. ${ }^{5}$ In that case, the Supreme Court stuck down the Gun-Free School Zones Act, which prohibited the possession of a firearm on school property, as an unconstitutional exercise of Congress's Commerce Clause authority, marking the first time since the New Deal that the Court invalidated congressional legislation passed under its Commerce Clause authority. Thus, the key case fact is the exercise of the Commerce Clause 
as justification for a congressional action. To be sure, Lopez was a major decision. Perry $(2005,29)$ refers to it as the "counterrevolution that was," while Abernathy (1996, 617) notes that Lopez marked "the return of federalism as an important issue at the Supreme Court." Still others went further: the subtitle of Homan's (1995) treatment of the decision and its impact was not-so-subtly titled "The Supreme Court Guns Down the Commerce Clause" and St. Laurent (1997, 61) describes the decision as "firmly [setting] to rest the notion that the Commerce Clause is the "Hey, you-can-do-whatever-you-feel-like Clause." "6 While others have sought to determine the relevance of Lopez on Commerce Clause cases in a variety of case studies, involving issue areas as wide ranging as crime control (Brickey 1996) and environmental law (Holman 1995), it has not yet been subjected to empirical scrutiny as a jurisprudential regime. Accordingly, I do so here. If Lopez marked a major shift in the Court's treatment of Congress's Commerce Clause authority, I hypothesize that, following Lopez, the justices will be more likely to vote in favor of states' rights challenges to congressional legislation passed under the authority of the Commerce Clause.

\section{Institutional Constraints}

By its very nature, the Court's federalism jurisprudence involves the scope of the power of the federal government vis-à-vis that of the states. As such, it is expected that the justices will be attentive to institutional constraints implicated in these cases in two ways. With regard to Congress, I expect that, as a national policy making institution, the Court will be particularly sensitive to striking down congressional laws, as opposed to state or local legislation (Dahl 1957). ${ }^{7}$ Such is the case for two reasons. First, because Congress has authority over the Court that state and local governments lack, including control over the federal judiciary's budget and jurisdiction, this has the potential to create a constraint on the justices to avoid drawing the ire of their legislative counterpart (Cross and Tiller 2000). In this sense, by ruling in favor of the pro-federal government side of the coin, a justice is able to sidestep separation of powers concerns that have the potential to undermine the Court's power and legitimacy. Second, a justice might avoid striking down congressional legislation in order to enlarge the Court's influence by expanding the breadth of federal law. For example, by striking down state legislation that conflicts with federal laws, a justice is able to enhance the Court's authority to adjudicate future litigation falling under the same issue area- a consideration that the justices, in their capacity as policy maximizers, might find particularly attractive. Conversely, by striking down federal legislation, a justice puts the Court in a position to potentially limit its authority to conduct judicial review, particularly if Congress fails to act by revising the legislation in question. Accordingly, I hypothesize that a justice will be less 
likely to support the states' rights position if the case implicates congressional authority.

Above, I have posited that the justices will consider the ramifications of their federalism decisions on the legislative branch of the federal government. However, it is important to note that the executive branch can also potentially constrain the justices' decision making by ignoring or indifferently enforcing the Court's decisions (Epstein and Knight 1999). As such, it is not surprising that the President regularly sends the justices unambiguous signals regarding the preferences of the executive branch via the Solicitor General's participation as both a party and an amicus curiae to a case. ${ }^{8}$ Indeed, scholars have found robust support for the important role of the Solicitor General in shaping the justices' decision making, both as a party (Cohen and Spitzer 2000) and as an amicus (Salokar 1992). Of course, it is important to note that, while federalism cases necessarily involve the powers of the federal government versus those of the states, the Solicitor General does not uniformly support the anti-states' rights position, even as a party. For example, in Ewing v. California (2003), the Solicitor General filed an amicus brief supporting California's "three strikes" law, which mandated a life sentence for persons convicted of a third felony, despite concerns that the policy was at odds with the Eighth Amendment of the U.S. Constitution. Similarly, in Mitchell $v$. Helms (2000), the Solicitor General, representing the Secretary of Education as a nominal respondent, supported a local government policy that loaned federally subsidized educational materials to religious instructors, despite the First Amendment issue implicated by the case. Contrarily, in Gonzales v. Raich (2005), the Solicitor General argued that California's Compassionate Use Act, which authorized the medicinal use of marijuana, was outside the scope of state authority as it conflicted with the congressionally passed Controlled Substances Act. As these examples make clear, the Solicitor General participates both in support of, and in opposition to, states' rights positions subsumed by federalism cases. As such, I hypothesize that, when the Solicitor General supports the states' rights position, a justice will be more likely to vote in favor of that position. Conversely, when the Solicitor General opposes the states' rights position, a justice is expected to be more likely to vote against that position.

\section{Organized Interests}

Interest group amicus curiae participation has become an important feature of Supreme Court litigation, particularly in the Rehnquist Court's federalism cases. Indeed, in the cases under analysis here, the justices saw an average of eight briefs per case (standard deviation=11). While the levels of interest group amicus activity are well documented in the Rehnquist Court (Owens and Epstein 2005), the influence of amici on the justices' decision making is less clear 
(compare, for example, Songer and Sheehan 1993 with Collins 2004), particularly in federalism cases (but see Colker and Scott 2002). Thus, this analysis provides an auspicious opportunity to determine if amici shape the choices justices make in federalism litigation. In federalism issues, the justices are confronted not only with a case's ramifications for the future of federalism, but also with its potential implications for public policy.

I expect that the justices will be receptive to information that assists them in determining the correct application of the law in a case, a task amicus briefs can perform in two ways. First, amicus briefs often provide the justices with information regarding the preferences of other actors in the political system, such as Congress, the President, and state and local governments (Epstein and Knight 1999, 215). Inasmuch as federalism cases are expected to make the justices particularly sensitive to other actors in the political arena (as they necessarily concern both state and federal activities), it is expected that the justices will pay close attention to the information provided to them in amicus briefs regarding these actors' preferences. Second, in addition to providing information regarding the preferences of other actors, amicus briefs also serve as a primary method by which the justices obtain information regarding the potential societal consequences of a decision (Collins 2004). In this capacity, amicus briefs inform the justices of how upholding or striking down a statute will affect members of society at large, information the justices are expected to find particularly useful for maximizing their policy goals. Of course, it is important to recall that, despite their literal translation ("friend of the court"), amicus briefs, are, in fact, adversarial in nature-almost always advocating for a particular outcome (Kearney and Merrill 2000). In this sense, amicus briefs are instruments of persuasion, directing the justices toward endorsing a particular outcome. As such, when a large number of amicus briefs are filed supporting, for example, the pro-states' rights position, these briefs provide the justices with information regarding both the breadth of support for the state policy in question and persuasive argumentation regarding why the states' rights position is jurisprudentially correct. Accordingly, I hypothesize that, as the number of amicus briefs supporting the states' rights perspective increases, so too will the likelihood of observing a justice cast a vote in favor of the states' rights position. Conversely, I expect that, as the number of amicus briefs opposing the states' rights position increases, a justice will be less likely to endorse that position.

While all interest groups have the potential to influence the justices' decision making in federalism cases, a number of groups exist that specifically represent the interests of state and local governments through the filing of amicus curiae briefs. Here I consider four such organizations, the Council of State Governments, the National Conference of State Legislatures, the National Governors Association, and the National League of Cities. Beginning in the 1960s, and with increased 
persistence over time, these organizations have been extremely active in their Washington lobbying efforts and frequently work together in the judicial arena by orchestrating litigation strategies on behalf of state and local governments (Chen 2003; Pickerill 2003). Most commonly, these organizations do so by cosigning amicus curiae briefs (Colker and Scott 2002). As Pickerill and Clayton (2004, 239) note, these organizations do much more than defend the constitutional principles of federalism in their litigation efforts: they also counter challenges to state and local policies involving federal pre-emption and national supremacy. Surprisingly, though, there has been little research evaluating the effectiveness of these organizations in the Court (but see Colker and Scott 2002). If these organizations are influential at fending off challenges to the constitutionality of state or local authority, I expect that a justice will be more likely to vote in favor of the states' rights position when one or more of these organizations participate as amicus curiae. ${ }^{9}$

\section{Data and Methodology}

Past studies investigating the justices' decision making in federalism cases have utilized a variety of strategies to select cases for analysis. For example, Kearney and Sheehan (1992) examine only cases in which state or local governments appear as litigants, while others select a more limited typology of cases, such as those involving the possible invalidation of state (Colker and Scott 2002) or federal law (Colker and Brudney 2001). Still others utilize an even more restrictive strategy, such as only including cases in which the word "federalism" appeared in an opinion (Cross and Tiller 2000) or those in which the Supreme Court reviewed a decision from a state court of last resort (Davis 1992). As such, none of these previous studies contains the full universe of federalism cases before the Court, which I do so here by examining every case that implicated a federalism dimension during the Rehnquist Court (1986-2004). In order to select cases for analysis, I began with a working definition of federalism. Following Cross (1999, 1304), I define federalism as the division of powers between a central government and its peripheral units, in which the central conflict involves the power of the states to operate free from federal interference (see also Solimine 2002). Thus, federalism disputes typically involve two types of cases: challenges to state and local laws alleged to be in discord with the federal Constitution (in its capacity as supreme law of the land), congressional legislation, and/or federal bureaucratic policies; and challenges to federal legislation or administrative policies that are argued to be inconsistent with state sovereignty.

In order to capture all cases that involve federalism in the Rehnquist Court, I utilize a three-prong strategy. ${ }^{10}$ First, I include all cases in which a state or local government, or an agent of a state or local government (e.g., governor, secretary 
of education), appeared as a party to litigation. These cases include challenges to state and local policies alleging a conflict with congressional legislation, administrative policies, and/or the federal Constitution. Second, I examined all cases in which the Supreme Court reviewed a decision from a state court of last resort and then analyzed each of these cases to determine if they implicated federalism (i.e., involved challenges to federal law based on the doctrine of state sovereignty or challenges to state law based on federal supremacy). For example, I include Bush v. Gore (2000), which concerned the power of states to set their own standards for counting contested electoral ballots, but exclude Chesapeake and Ohio Railway v. Schwalb (1989), which centered on whether injured railway laborers were covered by the Federal Employers' Liability Act or the Longshoremen's and Harbor Workers' Compensation Act, as the case did not involve either national supremacy or state sovereignty. Third, I scrutinized all cases falling under the Constitution's Commerce Clause, Contract Clause, Extradition Clause, Guarantee Clause, Privileges and Immunities Clause, and Supremacy Clause to determine whether they encompass a federalism dimension. The majority of these cases were identified using the previous two methods, but this third strategy located a number of highly salient cases, including United States v. Lopez (1995), United States v. Morrison (2000), and Gonzales v. Raich (2005). After excluding cases falling under the Court's original jurisdiction and those in which a state or local government squared off against another state or local government, I was left with 809 cases, which, using the case citation as the unit of analysis, made up 31 percent of the Rehnquist Court's docket (1986-2004). ${ }^{11}$

The unit of analysis used in this investigation is the justice-vote (i.e., each justice's vote in each case). The dependent variable is scored 1 for a vote consistent with the states' rights position and 0 for a vote in accordance with federal supremacy. In cases involving constitutional challenges to state or local policies, this means a pro-states' rights vote supports the state or local policy at issue, while a pro-federal government vote supports the litigant challenging the state or local policy as being in violation of the federal Constitution. In cases involving pre-emption, a pro-states' rights vote is anti-federal pre-emption, while a pro-federal government vote supports federal preemption of a state or local policy. In the context of the Commerce Clause, a pro-states' rights vote supports limitations on Congress's Commerce Clause authority, while a pro-federal government vote validates the congressional action at issue. For Tenth Amendment cases, a pro-states' right vote rejects congressional attempts to expand on its authority beyond those powers enumerated to it in the Constitution, while a pro-federal government vote authorizes the congressional action at issue. In cases involving the Eleventh Amendment, a pro-states' rights vote invalidates congressional attempts to abrogate states' sovereign immunity from federal lawsuits, either by striking down the congressional legislation at issue 
or by immunizing states from the remedies articulated in the congressional action, while a pro-federal government vote validates congressional actions serving to abolish states' sovereign immunity. In the context of conditional spending, a prostates' rights vote invalidates congressional attempts to attach conditions on the receipt of federal funds, while a pro-federal government vote endorses Congress's ability to set such conditions. For cases involving the Privileges and Immunities Clause, a pro-states' rights vote authorizes state legislation that sets residency requirements for, or restrictions on, access to state programs, while a pro-federal government vote supports the invalidation of these state policies. Because the dependent variable is dichotomous, I employ a probit model. To control for the nonindependence of observations (the fact that there are, on average, nine observations for each case in the data) and to limit the effects of model misspecification, the model is estimated using robust standard errors, clustered on case citation (King 1998, 34).

In order to capture each justice's Ideology, I utilize the Martin and Quinn (2002) scores. These scores are based on a dynamic item response model with Bayesian inference and thus vary over time. ${ }^{12}$ To facilitate interpretation, I have rescaled these scores by adding 4.332 to each ideal point; as such, this variable ranges from 0 to 7.784 . Higher scores on this variable reflect more conservative ideologies. Accordingly, the expectation is that this variable will be positively signed, indicating that conservative justices are more likely to support state and local policies under challenge.

To measure a justice's ideological proximity to the state policy at issue, I began by coding each case on its policy dimension. To do this, I relied on Spaeth's (2006) ideological direction variable for cases Spaeth did not categorize as involving federalism issues. I then determined the ideological direction of the state or local policy in contention. ${ }^{13}$ For example, if the lower court made a conservative ruling, in favor of the state policy at issue, I assume the state's policy is conservative in direction. Conversely, if the lower court rendered a liberal ruling, in favor of the state policy under review, I assume the state's policy is liberal in direction. For cases Spaeth categorized as solely involving federalism issues, I applied his coding scheme to these cases to determine the ideological direction of the state policy at issue. Thus, for example, I code the state policy in Howlett v. Rose (1990) as conservative because the state action in question involved an allegedly illegal search of a high school student's car. Similarly, I code the state policy in Lorillard Tobacco v. Reilly (2001) as conservative since the state policy in question sought to restrict the free speech rights of Lorillard Tobacco.

I then adapted the method developed by Johnson, Wahlbeck, and Spriggs (2006) to determine each justice's Ideological Proximity to the state or local policy under review. To do this, I first created a variable that measured each justice's ideological proximity to the state or local policy based on the unadjusted Martin and Quinn scores (which range from -4.332 to 3.452 ) by assigning 
liberal state policies the negative value of each justice's Martin and Quinn score and conservative policies each justice's Martin and Quinn score. I then added 4.332 to this variable to facilitate interpretation. As such, higher scores on this variable reflect increased ideological proximity to the state policy at issue. Accordingly, the expected sign of this variable is positive, indicating that a justice is more likely to support state or local policies that are ideologically in-line with his or her preferences.

To capture a case's salience, I use the measure created by Epstein and Segal (2000). ${ }^{14}$ This Case Salience variable is scored 1 if the case appeared on the front page of the New York Times on the day after the decision and 0 if it did not. Note that I have no expectations for the direction of this variable alone. ${ }^{15}$ Instead, I use it to determine whether salient cases enhance the likelihood of observing a justice who is ideologically distant from the state or local policy cast a vote against that policy, by including an interaction term in the model Ideological Proximity $\times$ Case Salience. Because I cannot infer from the magnitude and significance of the interaction term whether case salience exacerbates the extent to which an ideologically distant justice will cast a vote against the state or local policy (Ai and Norton 2003), it is necessary to calculate the marginal effect and confidence intervals for the interaction term, holding all other variables at their mean or modal values. To do this, I utilize the method developed by Brambor, Clark, and Golder (2006).

In order to evaluate whether a justice's state or local political experience influences his or her decision making in federalism cases, I include a variable labeled State Office, scored 1 if a justice held state or local office prior to his or her appointment to the bench and 0 otherwise, using information provided by the Federal Judicial Center (www.fjc.gov). Thus, this variable is scored 1 for Justices Powell (school board chairman), O'Connor (assistant state attorney general, state senator, state judge), Souter (assistant state attorney general, deputy state attorney general, state attorney general, state judge), and Thomas (assistant attorney general). ${ }^{16}$ The expected sign of this variable is positive, indicating that a justice with prior experience in state or local politics will be more likely to support state or local policies in question.

To capture the possible effects of the Lopez regime, I include three variables in the model. Lopez is scored 0 prior to the Lopez decision and 1 after the decision. Commerce Clause is scored 1 if the justification for the congressional legislation at issue involved the Commerce Clause and 0 otherwise. Note that I do not have expectations regarding the direction of these constituent variables. Instead, I utilize them to form an interaction term, Lopez $\times$ Commerce Clause, which allows me to test the possible impact of the Lopez regime. As with the previously mentioned interaction term, it is necessary to calculate the marginal effect of this term and its significance level, as the parameter estimate does not necessarily indicate the effect 
of an interaction term in maximum likelihood estimation. If the Lopez regime significantly altered the justices' decision making in Commerce Clause cases, I expect the marginal effect of this interaction term will be positive, indicating that a justice is more likely to vote against congressional legislation passed under the Commerce Clause after the establishment of the Lopez regime.

In order to account for institutional constraints, I include three variables in the model. To determine whether a justice is less likely to vote against congressional legislation due to possible retaliation by Congress, I include a Congress variable in the model, scored 1 if the Supreme Court's decision involved federal statutory interpretation and 0 otherwise. The expected direction of this variable is negative, indicating that a justice is less likely to vote against congressional legislation. To capture the influence of the Solicitor General in the Court, I include two variables. ${ }^{17}$ SG Party is scored 1 if the Solicitor General appeared as a litigant (or cross-litigant) supporting the state or local policy in question, 0 if the Solicitor General did not participate as a party in the case, and -1 if the Solicitor General represented the litigant opposed to the state or local policy at issue (i.e., the federal government). Similarly, SG Amicus is scored 1 if the Solicitor General filed an amicus brief in support of the state or local policy being challenged, 0 if the Solicitor General did not participate as amicus, and -1 if the Solicitor General filed an amicus brief opposing the state or local policy. Accordingly, I expect these variables will be positively signed, indicating that a justice is more likely to endorse the state or local policy when it is supported by the executive branch of the federal government.

To capture the influence of organized interests in the Court, three variables are utilized. Amici Supporting State indicates the number of amicus briefs filed in support of the state or local policy at issue, while Amici Opposing State represents the number of amicus briefs filed in opposition to the state or local policy implicated in the case. The expected direction of the former variable is positive, while I expect the latter variable will be negatively signed. To account for the amicus curiae participation of the Council of State Governments, the National Conference of State Legislatures, the National Governors Association, and the National League of Cities, I include a variable labeled State Interest Groups, scored 1 if one or more of these organizations filed an amicus brief in support of the state or local policy and 0 otherwise. The expected direction of this variable is positive, indicating that a justice is more likely to endorse the states' rights position if these organizations filed an amicus brief supporting it. Finally, in order to capture the justices' well-known practice of accepting cases for review in order to reverse lower court decisions (Segal and Spaeth 2002), I include a Lower Court Opposed State variable, scored 0 if the lower court the Supreme Court is reviewing rendered a decision in support of the state or local policy and 1 if it handed down a decision against the state or local policy. The expected direction of this variable is positive, 
indicating that a justice is more likely to support the state or local policy if the lower court opposed it.

\section{Results}

Table 1 reports the results of the probit model that examines influences on the justices' decision making in federalism cases. In the 809 cases under analysis, 3,721 votes were cast supporting the state or local policies at issue (51 percent), while 3,542 votes were cast opposing these policies (49 percent). Overall, the model performs exceptionally well-it correctly predicts more than 70 percent of votes for

Table 1 Probit model of the justices' federalism decision making in the Rehnquist Court era

\begin{tabular}{|c|c|c|c|c|}
\hline Variable & & $\begin{array}{l}\text { Expected } \\
\text { direction }\end{array}$ & Parameter estimate & Marginal effect \\
\hline \multicolumn{5}{|l|}{ Attitudes } \\
\hline Ideology & & + & $0.115(.013)^{* * *}$ & $+9.8^{* * *}$ \\
\hline Ideological Proximity & & + & $0.174(0.013)^{* * *}$ & $+13.9^{* * *}$ \\
\hline Ideological Proximity $\times$ Case Salience & & + & $0.090(0.032)^{* *}$ & see figure 1 \\
\hline \multicolumn{5}{|l|}{ Background } \\
\hline State office & & + & $-0.055(0.023)^{*}$ & $-2.2^{*}$ \\
\hline \multicolumn{5}{|l|}{ Jurisprudential regime } \\
\hline Lopez $\times$ Commerce Clause & & + & $-0.290(0.303)$ & -11.6 \\
\hline \multicolumn{5}{|l|}{ Institutional constraints } \\
\hline Congress & & - & $0.155(0.078)^{*}$ & $+6.1^{*}$ \\
\hline SG Party & & + & $0.325(0.138)^{*}$ & $+13.0^{*}$ \\
\hline SG Amicus & & + & $0.341(0.058)^{* * *}$ & $+13.5^{* * *}$ \\
\hline \multicolumn{5}{|l|}{ Organized interests } \\
\hline Amici supporting state & & + & $0.015(0.005)^{* *}$ & $+4.3^{* * *}$ \\
\hline Amici opposing state & & - & $0.001(0.008)$ & +0.02 \\
\hline State interest groups & & + & $0.197(0.097)^{*}$ & $+7.8^{*}$ \\
\hline \multicolumn{5}{|l|}{ Control and constituent variables } \\
\hline Lower court opposed state & & + & $0.393(0.066)^{* * *}$ & $+15.6^{* * *}$ \\
\hline Commerce clause & & none & $0.906(.236)^{* * *}$ & $+34.2^{* * *}$ \\
\hline Lopez & & none & $-0.047(0.072)$ & -1.9 \\
\hline Case salience & & none & $-0.502(.159)^{* *}$ & $-17.9^{* * *}$ \\
\hline Constant & & none & $-1.59(0.093)^{* * *}$ & \\
\hline \multicolumn{5}{|l|}{ Model diagnostics } \\
\hline$N$ & 7,263 & Percent $\mathrm{c}$ & correctly predicted & 70.7 \\
\hline Wald $\chi_{(\mathrm{df}=16)}^{2}$ & $503.4^{* * *}$ & Percent $\mathrm{r}$ & eduction in error & 39.9 \\
\hline
\end{tabular}

Numbers in parenthesis indicate robust standard errors, clustered on case citation. ${ }^{*} P<0.05 ;{ }^{* *} P<0.01 ;{ }^{* *} P<0.001$ (two-tailed tests). 
a percent reduction in error of 40 percent, thus clearly indicating that it is inappropriate to view the justices' federalism decision making as inconsistent or bewildering. Of equal import, the model yields substantial information about the justices' choices in these cases. In order to facilitate the interpretation of these results, I report marginal effects, which are calculated by altering the variables of interest from 0 to 1 for dichotomous variables and from the mean to 1 standard deviation above the mean for continuous variables, holding all other variables at their mean or modal values.

Beginning with the results consistent with attitudinal theories of judicial decision making, note that all variables are signed in the correct direction and are statistically significant. The Ideology variable indicates that conservative justices are more likely than their liberal counterparts to support state and local policies. For example, compared to a moderate justice (Ideology $=4.4$ ), a relatively conservative justice (Ideology $=6.4$ ) is 10 percent more likely to vote in support of the states' rights position. This effect is especially evident when we consider the difference between an extremely liberal (Ideology $=1.2$ ) and an extremely conservative justice (Ideology $=7.2$ ): the liberal justice is 26 percent more likely to take the pro-federal government stance in the case. In addition, the Ideological Proximity variable indicates that, the more proximate a justice is to the state or local policy, the more likely that justice is to support it. For example, a 1 standard deviation change in this variable increases the likelihood of observing a justice take the states' rights position by almost 14 percent in a non-salient case. Thus, not only are conservative justices more likely to support states' rights, but they are also particularly likely to do so when those policies match their political preferences.

Figure 1 examines how a case's salience further exacerbates the effect of a justice's ideological proximity to the state or local policy involved in the case. The solid line indicates the change in the predicted probability of observing a justice vote in favor of states' rights in a salient case as a justice becomes more ideologically proximate to the state or local policy, as compared to a non-salient case. Significance levels are denoted by the 95 percent confidence intervals drawn around this line. The marginal effect is significant whenever the upper and lower bounds of the confidence intervals are both below (or above) the zero line. Consistent with my hypothesis, justices who are ideologically distant from the state or local policy are especially likely to vote against that policy in salient cases. To more lucidly illustrate this point, consider the following scenario. When a state policy is conservative in direction, and the justice is very liberal, and the case is salient, that justice is 10 percent more likely to vote against the state policy, compared to a non-salient case. Interestingly, this effect only holds for justices whose ideologies are relatively strong. For the more moderate justices on the Court, whose ideological distance to the policy at issue are within 4 points, a case's salience does not further enhance their likelihood of supporting or opposing 


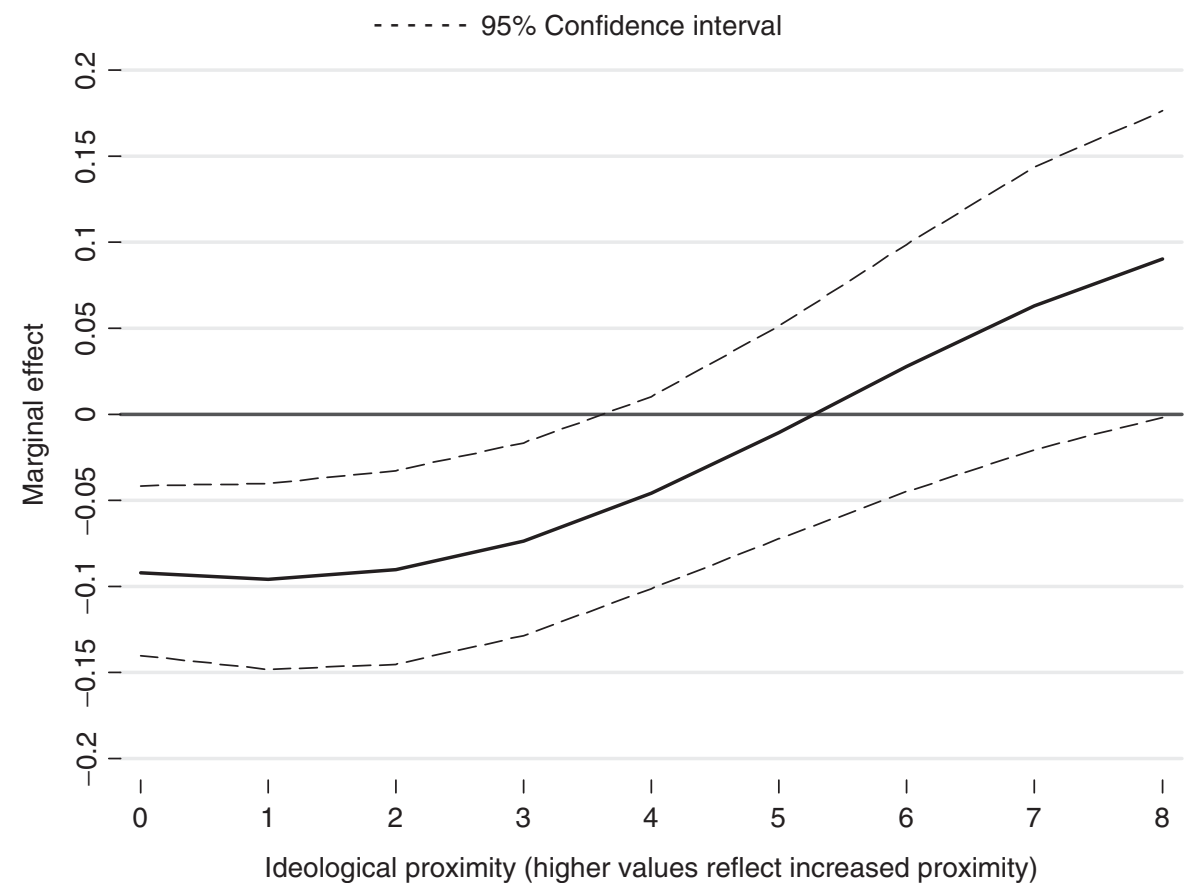

Figure 1 The marginal effect of case salience on a justice's ideological proximity to state and local policies.

the states' rights position. This indicates that there are considerable differences between salient and non-salient cases: in relatively insignificant cases, in which legal issues tend to uncontroversial, extremist justices rely less on their attitudes in their decision making, while attitudinal behavior is especially enhanced in cases that have broad ramifications for the political system at large. Taken as a whole, Table 1 illustrates strong support for the attitudinal model of judicial decision making in federalism cases. Conservative justices are more likely than their liberal counterparts to endorse state and local policies, and this proves particularly true if the state policy at issue is ideologically proximate to the justices' political preferences. Further, those justices who are ideologically distant from state policies are not only more likely to endorse the pro-federal government position, but are particularly likely to do so in salient cases.

Turning now to the variable that captures whether a justice had experience in state or local politics prior to serving on the Supreme Court, the results fail to support my expectation. In fact, the marginal effect of this variable indicates that justices who held state or local office are 2 percent less likely to support state and 
local governments as compared to justices who did not occupy such positions. In part, this finding might reflect the fact that the justices who exhibit the strongest support for states' rights-Rehnquist (71 percent of votes in favor of states rights), Thomas (69 percent), and Scalia (66 percent)—were all employed by the federal government under Republican presidencies. Conversely, Marshall, who supported the states' rights position less than 22 percent of the time, served as Solicitor General under Johnson, a Democrat. Thus, these results appear to indicate that state and local offices are not especially productive breeding grounds for states' rights philosophies. Instead, Republican presidential administrations seem to be effective in cultivating Supreme Court justices with a clear proclivity towards supporting states' rights.

The results of the Lopez regime are particularly interesting. Contrary to my hypothesis, there was not a significant change in the justices' treatment of Commerce Clause cases following the establishment of Lopez doctrine. In fact, the constituent term, which indicates the justices' voting behavior in Commerce Clause cases prior to Lopez, suggests that the Rehnquist Court justices were generally supportive of limitations to Congress's Commerce Clause authority, even before Lopez. Thus, it appears that the effect of Lopez has likely been overstated. While Lopez was the first instance of the Court striking down an act of Congress under its Commerce Clause authority since the New Deal, this does not mean that the Court entirely deferred to Congress on such matters (Bednar and Eskridge 1995, 1451). For example, in CTS Corporation v. Dynamics Corporation (1987), the Court declined to strike down an Indiana statute as violating the Commerce Clause, in addition to refusing to determine that the law was pre-empted by the Williams Act, thus further increasing the power of states to regulate the acquisition of control shares in certain types of corporations. Similarly, in Northwest Central v. State Corporation Commission (1988), the Court refused to invalidate a state law involving gas regulation and also would not rule that it was pre-empted by the Natural Gas Act. Therefore, it appears unlikely that Lopez signaled a major shift in the justices' treatment of Congress's Commerce Clause authority, which is consistent with arguments made by a number of scholars (Cross 1999: 1322; Friedman 1997, 336) who characterize that decision as anomalous and unlikely to have much impact on the Court's attempts to limit Congressional power. As such, it appears best to view Lopez as a somewhat uncharacteristic bump in the road, rather than a major revolution in the Court's treatment of Commerce Clause cases. ${ }^{18}$

The findings regarding the variables that capture institutional constraints facing the justices reveal mixed results. On the one hand, a justice is not more likely to cast a pro-federal government vote when the case involves congressional 
legislation, as compared to the federal Constitution. In fact, contrary to my expectations, the marginal effect of this variable indicates that a justice is 6 percent more likely to take the states' rights position when the case implicates an act of Congress. Thus, these results appear to corroborate Pickerill's (2003) conclusion that one can properly view the Rehnquist Court's federalism decisions as limiting federal legislative powers. On the other hand, Table 1 reveals strong evidence that the justices defer to the Solicitor General. When the Solicitor General appears as a party opposing a state government, a justice is 12 percent more likely to vote against the state policy as compared to a case in which the SG does not appear as a party. Conversely, when the Solicitor General appears as a litigant supporting the state or local policy, a justice is 13 percent more likely to take the states' rights position. This strong influence also holds for cases in which the Solicitor General appears as an amicus curiae: compared to a case in which the Solicitor General does not file an amicus brief, when the Solicitor General files an amicus brief in support of the state policy, a justice is 13 percent more likely to take the pro-states' rights position. Thus, while the justices do not appear to respond to congressional constraints, they do defer to the interests of the executive branch in federalism cases.

Turning to the findings with respect to the influence of organized interests, Table 1 reveals that organized interests who support state or local policies have a significant influence on the justices' decision making. Compared to a case in which there are four briefs supporting the state or local policy, in a case with eleven briefs (a 1 standard deviation change), a justice is 4 percent more likely to take the states' rights position. Moreover, when the Council of State Governments, the National Conference of State Legislatures, the National Governors Association, and/or the National League of Cities participate as amici curiae, a justice is 8 percent more likely to endorse the state or local policy at issue. As such, the results indicate that these organizations are particularly effective in persuading the justices to endorse states' rights positions. Interestingly, Table 1 indicates that amicus briefs filed in opposition to state or local policies do not influence the justices' decision making in federalism cases. Finally, the control variable reveals that, when the lower court opposed the state policy, a justice is 16 percent more likely to take the states' rights position, thus confirming the justices' tendency to take cases on appeal in order to reverse lower courts. ${ }^{19}$

\section{Conclusions}

The purpose of this article was to develop an integrated model of judicial decision making in federalism cases and subject it to empirical scrutiny in the Rehnquist Court. 
The results clearly reveal that the justices' decisions in federalism cases are not as inconsistent and bewildering as some commentators believe. In fact, they are quite predictable: the model was able to correctly classify more than 70 percent of the justices' votes in cases dealing with the boundaries of state versus federal power. How then can we best characterize the justices' federalism decisions? First, it is evident that attitudes matter. Conservative justices are more likely than their liberal counterparts to support state and local policies. Moreover, a justice's ideological proximity to the state policy is also consequential: the further a justice is from the state policy, the less likely that justice is to support that policy and this effect is exacerbated in salient cases. Thus, to the extent that the justices take federalism seriously, they evidently do so-in part-to further their policy goals. However, attitudes are not the only determinant in federalism cases. Clearly, the preferences of the President matter, as relayed to the Court via the Solicitor General. But, the Court is not especially deferential to congressional legislation, suggesting that one of the legacies of the Rehnquist Court's federalism jurisprudence was to limit federal legislative powers. In addition, the results reveal that amicus curiae participation matters by enabling organized interests to show broader support for state and local policies, while buttressing the arguments made by the litigants they support. And, while the Lopez regime does not appear to mark a major shift in the Court's federalism jurisprudence, taken as whole, the results of the integrated model of federalism decision making are promising in their ability to illustrate consistent patterns in what many see as one of the most ambiguous issue areas of Supreme Court decision making. Further, given that seven of the justices analyzed here transferred to the Roberts Court, and the two new appointees are at least as conservative as their predecessors, it is likely that we will see these trends continue through the Roberts Court era.

Of course, it is imperative to note that, while I have provided evidence that the justices' decision making in federalism cases is relatively predictable, I have not attempted to evaluate the validity of the Rehnquist Court's so-called "federalism revolution." As such, a number of other questions await future study. For example, it will be important to determine whether the hypotheses proposed here are equally applicable to earlier Courts. Through such longitudinal analyses, scholars will be well equipped to determine how membership change and other jurisprudential regimes influence federalism decision making. Moreover, such studies will offer leverage over whether the behavior of the Rehnquist Court justices significantly differed from that of their earlier counterparts, thus offering the ability evaluate claims of a federalism revolution. As such, a resurgence of empirically oriented scholarship on the justices' federalism decision making, integrating a number of theoretical perspectives, will surely lead us toward a more thorough 
understanding of the Supreme Court's treatment of the boundaries between state and federal power.

\section{Notes}

I thank Chris Nicholson for his exemplary research assistance and John Kincaid, Susan Mezey, Nancy Scherer, and the anonymous reviewers for excellent comments on this research. An earlier version of this article was presented at the 2006 Annual Meeting of the American Political Science Association. This research was supported in part by National Science Foundation Research Grant SES-0350416. Naturally, any errors remain my own.

1. As discussed subsequently, a substantial debate exists as to whether the justices genuinely consider federalism values as an important determinant in their decision making. Further, it should be noted that the apparent hypocrisy in the federalist five's treatment of federalism in Bush v. Gore is in no way unique to conservative justices. Rather, both liberal and conservative justices routinely buttress their opinions with federalism principles to further their political goals (Cross 1999, 1310).

2. New York v. United States, 505 U.S. 144, at 149 (1992).

3. See, for example, Baybeck and Lowry (2000) examining only pre-emption cases, Colker and Scott (2002) investigating only cases involving the invalidation of state actions, and Eskridge and Ferejohn (1994) limiting their analysis to Commerce Clause cases.

4. Clearly, not all conservatives have a genuine attachment to states' rights, just as not all liberals favor an expansive interpretation of federal power (Cross 1999). However, as an empirical matter, I, nonetheless, expect that conservative justices will be more likely to endorse states' rights positions than liberal justices.

5. In addition to Lopez, I examined Seminole Tribe v. Florida and City of Boerne v. Flores as candidates for jurisprudential regimes in Eleventh Amendment cases that involved congressional attempts to abrogate state sovereign immunity from lawsuits. The results of those models indicate that neither case marked a significant shift in the justices' treatment of Eleventh Amendment cases.

6. Further corroborating the importance of this decision, a Lexis search of law reviews for "United States v. Lopez" in the title from 1995 to 2006 returns 83 separate articles.

7. Indeed, this point was especially apparent at the confirmation hearing of Justice Alito when Sen. Arlen Specter (R-PA) pushed Alito to enunciate his position on deference to the legislative branch in its capacity as an elected lawmaking institution vis-à-vis that of the courts since federal judges are appointed (Hearing Before the Senate Committee on the Judiciary, 109th Congress [2006] [statements of Senator Specter]).

8. Note that, on rare occasions, members of Congress also file amicus curiae briefs. However, unlike the Solicitor General, scholars have revealed that these briefs have virtually no influence on the justices' decision making (Heberlig and Spill 2000; McLauchlan 2005). As such, I exclude congressional amicus briefs from consideration.

9. There are, of course, a host of other organizations that represent the interests of state and local governments through the filing of amicus curiae briefs, such as the National 
Association of Attorneys General, the National Association of Counties, the National Institute of Municipal Law Officers, and the U.S. Conference of Mayors. I focus my attention here on the Council of State Governments, the National Conference of State Legislatures, the National Governors Association, and the National League of Cities as they are the most frequent amici representing the interests of local and state governments in the Court (Colker and Scott 2002; O'Connor and Epstein 1989). Further, because these organizations participate almost exclusively together (e.g., Gregory v. Ashcroft [1991] and Smith v. City of Jackson [2005]), I do not consider the influence of each organization separately. Likewise, I do not consider the influence of amicus briefs filed by state or local governments separately from the briefs filed by these organizations due to the high frequency with which both types of organizations participate on the same side of a case (e.g., Atwater v. City of Lago Vista [2001] and College Savings Bank v. Florida [1999]).

10. I began by locating cases in Spaeth's (2006) Supreme Court Database and read the individual cases as necessary. Unless otherwise noted, all of the data under analysis come from this data set.

11. In actuality, I located 844 cases. However, due to an inability to code the direction of the state policy at issue distinctly from the federalism dimension, I was forced to exclude 35 of these cases from this analysis. See, for example, Rose v. Rose (1987), Utah Division of Lands v. United States (1987), and Verizon v. Public Service Commission (2002).

12. While these scores are based on the justices' actual voting behavior, thus potentially introducing a circularity problem, their use is appropriate here because the voting behavior from which the vast majority of these votes (95 percent) are based deal with the policy dimension implicated by the case, not a case's federalism dimension (see also Baybeck and Lowry 2000).

13. For cases that encompass civil rights and liberties, liberal policies promote, for example, civil rights and liberties doctrines, such as the freedoms of speech and religion, and the right to privacy; conservative policies are the opposite thereof. In criminal justice cases, liberal policies promote the rights of the criminally accused, while conservative policies favor limiting these rights. In the realm of labor and economic regulations, policies that favor business over the interests of labor (or government regulators) are coded as conservative, while pro-labor and pro-government/anti-business policies are coded as liberal.

14. These data were collected by Epstein and Segal (2000) for the 1986-1995 terms and collected by the author for the remaining terms, using the coding rules established by Epstein and Segal.

15. I, nonetheless, include this constituent term, and those of the other interaction term, in the model because failure to do so leads to biased and inconsistent estimates of the interaction terms (Brambor et al. 2006, 66-70).

16. Justice Thomas is the only Rehnquist Court justice who held both state and federal offices prior to his service on the Court. That is, in addition to serving as Assistant Attorney General for Missouri, Thomas also served as Assistant Secretary for Civil Rights in the U.S. Department of Education and as Chairman of the Equal Employment Opportunity Commission. When Thomas is excluded from consideration in the coding of this variable, the results do not substantively differ. 
17. The data for the variables indicating the Solicitor General's participation in a case as party and amicus, as well as those representing the participation of organized interests as amici, come from the Kearney and Merrill (2000) amicus database for the 1986-1995 terms and were collected by the author for the remaining terms (1996-2004).

18. To check the robustness of this finding, I also estimated a model considering only Commerce Clause cases. That model also indicates that Lopez did not mark a major shift in the justices' treatment of Commerce Clause litigation.

19. While the Case Salience variable appears to have an enormous influence on the justices' decision making, it is inappropriate to make much of this effect because it only captures the influence of case salience on the most liberal justice in the data when the state policy is conservative. There are only eight observations that meet this criterion, all of which involve Justice Marshall in the 1988 term. In each of these cases, Marshall voted against the state policy in question.

\section{References}

Abernathy, Charles F. 1996. Federalism and anti-federalism as civil rights tools. Howard Law Journal 39 (Spring): 615-632.

Ai, Chunrong, and Edward C. Norton. 2003. Interaction terms in logit and probit models. Economics Letters 80 (1): 123-129.

Atwater v. City of Lago Vista, 532 U.S. 318 (2001).

Baybeck, Brady, and William Lowry. 2000. Federalism outcomes and ideological preferences: The U.S. Supreme Court and preemption cases. Publius: The Journal of Federalism 30 (3): 73-97.

Bednar, Jenna, and William N. Eskridge Jr. 1995. Steadying the Court's "unsteady path": A theory of judicial enforcement of federalism. Southern California Law Review 68 (6): 1447-1491.

Brambor, Thomas, William R. Clark, and Matt Golder. 2006. Understanding interaction models: Improving empirical analyses. Political Analysis 14 (1): 63-82.

Brickey, Kathleen F. 1996. Crime control and the commerce clause: Life after Lopez. Case Western Reserve Law Review 46 (Spring): 801-843.

Bush v. Gore, 531 U.S. 98 (2000).

Bush v. Vera, 517 U.S. 952 (1996).

Chen, Paul. 2003. The institutional sources of state success in federalism litigation before the Supreme Court. Law and Policy 25 (4): 455-472.

Chesapeake and Ohio Railway v. Schwalb, 493 U.S. 40 (1989).

City of Boerne v. Flores, 521 U.S. 507 (1997).

Cohen, Linda R., and Matthew L. Spitzer. 2000. The government litigant advantage: Implications for the law. Florida State University Law Review 28 (Fall): 391-425.

Colker, Ruth, and James J. Brudney. 2001. Dissing congress. Michigan Law Review 100 (October): 80-144. 
Colker, Ruth, and Kevin M. Scott. 2002. Dissing states?: Invalidation of state action during the Rehnquist era. Virginia Law Review 88 (6): 1301-1386.

College Savings Bank v. Florida, 527 U.S. 666 (1999).

Collins, Paul M. Jr. 2004. Friends of the Court: Examining the influence of amicus curiae participation in U.S. Supreme Court litigation. Law and Society Review 38 (4): 807-832.

Cross, Frank B. 1999. Realism about federalism. New York University Law Review 74 (5): 1304-1335.

Cross, Frank B., and Emerson Tiller. 2000. The three faces of federalism: An empirical assessment of Supreme Court federalism jurisprudence. Southern California Law Review 73 (4): 741-771.

CTS Corporation v. Dynamics Corporation, 481 U.S. 69 (1987).

Dahl, Robert A. 1957. Decision-making in a democracy: The Supreme Court as a national policy-maker. Journal of Public Law 6 (Fall): 279-295.

Davis, Sue. 1992. Rehnquist and state courts: Federalism revisited. Western Political Quarterly 45 (3): 773-782.

Epstein, Lee, and Jack Knight. 1999. Mapping out the strategic terrain: The informational role of amici curiae. In Supreme Court decision making: New institutionalist approaches, eds. C. Clayton, and H. Gillman. Chicago: University of Chicago Press.

Epstein, Lee, and Jeffrey A. Segal. 2000. Measuring issue salience. American Journal of Political Science 44 (1): 66-83.

Eskridge, William N. Jr, and John Ferejohn. 1994. The elastic commerce clause: A political theory of American federalism. Vanderbilt Law Review 47 (5): 1355-1400.

Ewing v. California, 538 U.S. 11 (2003).

Fallon, Richard H. Jr. 2002. The "conservative" paths of the Rehnquist Court's federalism decisions. University of Chicago Law Review 69 (2): 429-494.

Friedman, Barry. 1997. Valuing federalism. Minnesota Law Review 82 (2): 317-412.

Gonzales v. Raich, 545 U.S. 1 (2005).

Greenhouse, Linda. 2001. Will the Court reassert national authority? New York Times, September 30, sec. 4.

Gregory v. Ashcroft, 501 U.S. 452 (1991).

Heberlig, Eric, and Rorie Spill. 2000. Congress at court: Members of congress as amicus curiae. Southeastern Political Review 28 (2): 189-212.

Holman, J. Blanding IV. 1995. After United States v. Lopez: Can the Clean Water Act and the Endangered Species Act survive commerce clause attack? Virginia Environmental Law Journal 15 (Fall): 139-211.

Homan, Molly E. 1995. United States v. Lopez: The Supreme Court guns down the commerce clause. University of Denver Law Review 73 (1): 237-292.

Howlett v. Rose, 496 U.S. 356 (1990). 
Johnson, Timothy R., Paul J. Wahlbeck, and James F. Spriggs II. 2006. The influence of oral arguments on the U.S. Supreme Court. American Political Science Review 100 (1): 99-113.

Kearney, Joseph D., and Thomas W. Merrill. 2000. The influence of amicus curiae briefs on the Supreme Court. University of Pennsylvania Law Review 148 (3): 743-855.

Kearney, Richard C., and Reginald S. Sheehan. 1992. Supreme Court decision making: The impact of Court composition on state and local government litigation. Journal of Politics 54 (4): 1008-1025.

Kimel v. Florida Board of Regents, 528 U.S. 62 (2000).

King, Gary. 1998. Unifying Political Methodology: The Likelihood Theory of Statistical Inference. Ann Arbor, MI: University of Michigan Press.

Kissam, Philip C. 2006. Constitutional theory and ideological factors: Three nineteenthcentury justices. Kansas Law Review 54 (3): 751-802.

Kritzer, Herbert M., and Mark J. Richards. 2003. Jurisprudential regimes and Supreme Court decisionmaking: The Lemon regime and Establishment Clause cases. Law and Society Review 37 (4): 827-840.

2005. The influence of law in the Supreme Court's search-and-seizure jurisprudence. American Politics Research 33 (1): 33-55.

Lorillard Tobacco v. Reilly, 533 U.S. 525 (2001).

Martin, Andrew D., and Kevin M. Quinn. 2002. Dynamic ideal point estimation via Markov Chain Monte Carlo for the U.S. Supreme Court, 1953-1999. Political Analysis 10 (2): $134-153$.

McLauchlan, Judithanne Scourfield. 2005. Congressional participation as amicus curiae before the U.S. Supreme Court. New York: LFB Scholarly Publishing.

Mendelson, Wallace. 1964. The untroubled world of jurimetrics. Journal of Politics 26 (4): 914-922.

Mitchell v. Helms, 530 U.S. 793 (2000).

New York v. United States, 505 U.S. 144 (1992).

Northwest Central v. State Corporation Commission, 489 U.S. 493 (1988).

O'Connor, Karen, and Lee Epstein. 1989. Public Interest Law Groups: Institutional Profiles. Westport, CT: Greenwood Press.

Owens, Ryan J., and Lee Epstein. 2005. Amici curiae during the Rehnquist years. Judicature 89 (3): 127-133.

Perry, H. W. Jr. 1991. Deciding to Decide: Agenda Setting in the United States Supreme Court. Cambridge: Harvard University Press.

2005. Federalism: The counterrevolution that was, wasn't, was??? Law and Courts 15 (1): $28-31$.

Pickerill, J. Mitchell. 2003. Leveraging federalism: The real meaning of the Rehnquist Court's federalism jurisprudence for states. Albany Law Review 66 (3): 823-833. 
Pickerill, J. Mitchell, and Cornell W. Clayton. 2004. The Rehnquist Court and the political dynamics of federalism. Perspectives on Politics 2 (2): 233-248.

Richards, Mark J., and Herbert M. Kritzer. 2002. Jurisprudential regimes in Supreme Court decision making. American Political Science Review 96 (2): 305-320.

Rose v. Rose, 481 U.S. 619 (1987).

Salokar, Rebecca Mae. 1992. The Solicitor General: The Politics of Law. Philadelphia: Temple University Press.

Schenker, Carl R. Jr. 1982. Reading Justice Sandra Day O'Connor. Catholic University Law Review 31 (3): 487-503.

Segal, Jeffrey A., and Harold J. Spaeth. 2002. The Supreme Court and the Attitudinal Model Revisited. New York: Cambridge University Press.

Seminole Tribe v. Florida, 517 U.S. 44 (1996).

Smith v. City of Jackson, 544 U.S. 228 (2005).

Solberg, Rorie Spill, and Stefanie A. Lindquist. 2006. Activism, ideology, and federalism: Judicial behavior in constitutional challenges before the Rehnquist Court, 1986-2000. Journal of Empirical Legal Studies 3 (2): 237-261.

Solimine, Michael E. 2002. Judicial federalism after Bush v. Gore: Some observations. Justice System Journal 23 (1): 45-55.

Songer, Donald R., and Reginald S. Sheehan. 1993. Interest group success in the courts: Amicus participation in the Supreme Court. Political Research Quarterly 46 (2): 339-354.

Spaeth, Harold J. 1985. Burger Court review of state court civil liberties decisions. Judicature 68 (February-March): 285-291.

. 2006. The Original U.S. Supreme Court Judicial Database. East Lansing, MI: Department of Political Science, Michigan State University. Available at http:// www.as.uky.edu/polisci/ulmerproject/sctdata.htm.

St Laurent, Andrew. 1997. Reconstituting United States v. Lopez: Another look at federal criminal law. Columbia Journal of Law and Social Problems 31 (Fall): 61-117.

Tate, C. Neal. 1981. Personal attribute models of the voting behavior of U.S. Supreme Court justices: Liberalism in civil liberties and economics decisions, 1946-1978. American Political Science Review 75 (2): 355-367.

Tiller, Emerson H. 1995. Putting politics into the positive theory of federalism: A comment on Bednar and Eskridge. Southern California Law Review 68 (6): 1493-1502.

Unah, Isaac, and Ange-Marie Hancock. 2006. U.S. Supreme Court decision making, case salience, and the attitudinal model. Law and Policy 28 (3): 295-320.

United States v. Lopez, 514 U.S. 549 (1995).

United States v. Morrison, 529 U.S. 598 (2000).

Utah Division of Lands v. United States, 482 U.S. 193 (1987).

Verizon v. Public Service Commission, 535 U.S. 635 (2002).

Washington v. Glucksberg, 521 U.S. 702 (1997). 
Webster v. Reproductive Health Services, 492 U.S. 490 (1989).

Wise, Charles, and Rosemary O'Leary. 1992. Is federalism dead or alive in the Supreme Court? Implications for public administrators. Public Administration Review 52 (6): 559-572.

Young, Ernest A. 2005. Just blowing smoke? Politics, doctrine, and the federalist revival after Gonzales v. Raich. Supreme Court Review 2005 (1): 1-50. 